\title{
Application of metacognitive strategies in the development of emotional and motivational self-regulation of students with special educational needs. Research on children with ADHD
}

\author{
Kajka Natalia ${ }^{1,2}$ ABCD https://orcid.org/0000-0002-1781-6773, \\ Kulik Agnieszka² AEFG, https://orcid.org/0000-0002-1643-4159
}

${ }^{1}$ I Department of Psychiatry, Psychotherapy and Early Intervention, Medical University of Lublin, Poland ${ }^{2}$ Department of Psychotherapy and Health Psychology, The John Paul II Catholic University of Lublin, Poland

\begin{abstract}
The aim of the presented study is to verify whether the visual methods (Mind Maps and Sketch-noting) considered as metacognitive strategies will help to strengthen emotional and motivational self-regulation in children with ADHD. In this experimental study, 135 participants took part, including 45 primary school students diagnosed with attention deficit hyperactivity disorder with the presentation of mixed symptoms $(\mathrm{M}=10.41$; $\mathrm{SD}=1.42)$, their parents $(\mathrm{N}=45)$ and teachers $(\mathrm{N}=45)$. The results obtained in the study indicate that after 25 training sessions with the use of both Mind Maps and Sketchnoting, children with ADHD make significantly fewer errors than during the first measurement. However, only in the Sketchnoting group did their average reaction time increase significantly, which indicates that they are more reflective. The presented metacognitive strategies can be successfully applied at school by students with ADHD and constitute a source of support for both students and teachers.
\end{abstract}

Keywords: metacognitive strategies, ADHD, emotional and motivational self-regulation, special educational needs

\section{Streszczenie}

Celem prezentowanego badania jest weryfikacja, czy metody wizualne (Mapy Myśli i Notatki Wizualne) traktowane jako strategie metapoznawcze pomogą wzmocnić samoregulację emocjonalną i motywacyjną u dzieci z ADHD. W tym badaniu eksperymentalnym wzięło udział 135 uczestników, w tym 45 uczniów szkół podstawowych z rozpoznaniem zespołu nadpobudliwości psychoruchowej z deficytem uwagi z objawami mieszanymi $(M=10,41 ; S D=1,42)$, ich rodzice $(N=45)$ i nauczyciele ( $\mathrm{N}=45)$. Uzyskane w badaniu wyniki wskazują, że dzieci z ADHD popełniają znacznie mniej błędów po 25 sesjach treningowych z wykorzystaniem zarówno Mapy Myśli, jak i Notatek Wizualnych, niż podczas pierwszego pomiaru. Jednak tylko w grupie Notatek Wizualnych znacząco wzrósł średni czas reakcji dzieci, co wskazuje, że są one bardziej refleksyjne. Przedstawione strategie metapoznawcze mogą być z powodzeniem stosowane w szkole przez uczniów z ADHD i stanowią źródło wsparcia zarówno dla uczniów, jak i nauczycieli.
\end{abstract}

Słowa kluczowe: ADHD, strategie metapoznawcze, samoregulacja emocjonalna i motywacyjna, specjalne potrzeby edukacyjne

\section{Introduction}

Special Educational Needs of Children with ADHD

Children diagnosed with attention deficit hyperactivity disorder (ADHD) constitute nearly 5 - 7\% of the population. There is a trend showing an increase in the prevalence of this diagnosis with increasing age of children [1]. At school, they make up a group of students with special educational needs (SEN). This term was introduced in The Warnock Report of Special Educational Needs published 43 years ago in London by Her Majesty's Stationery Office [2]. The popularity of the report spred to other countries and the main advantage of the approach it promoted, was the transition from the subject categorization of students according to their medical diagnoses to the 
needs resulting from the diagnosed disorders. It was a landmark event in the education of children and youth that is being developed in many countries today. In Poland, the acronym SEN describes children with a spectrum of symptoms that make functioning difficult or impossible: motor, sensory, cognitive, communication, emotional, social and/or psychological, affecting the quality of life and fulfilling social roles now and/or in the future [3]. Children diagnosed with attention deficit hyperactivity disorder constitute one of the groups included in this classification. This means that they are more likely to have difficulties at school and need a dedicated form of support. Literature emphasizes that students with ADHD, compared to their healthy peers, are more likely to struggle academically, cannot learn effectively, have a slower pace of reading and processing information, and exhibit problematic behavior in the classroom. They are also rejected by their peers and have difficulties in establishing lasting social relationships [4-7]. The subject of special educational needs seems to be crucial in the context of the COVID-19 pandemic. Current research shows that adolescents with ADHD during lockdown lose the ability to learn in the remote system compared to in-class learning and that their ADHD symptoms intensify [8,9]. Becker et al. [8] indicate that it is imperative that schools and communities provide the necessary support to children diagnosed with ADHD.

\section{Emotional and motivational self-regulation}

One of the executive functions mentioned by Barkley [10] - emotional and motivational self-regulation (EMS) is responsible for the regulation of behavior when one is under the influence of strong emotions. According to the researcher, the experienced affect plays a significant role while assessing and defining both the child's goal and the manner of achieving it [11]. When EMS is properly developed, the student is able to regulate emotional tension, which allows him/her to adopt an objective attitude towards what happened (without an emotional context) as well as have control over motor reactions in the moment of strong agitation. Unfortunately, students with ADHD often have difficulties in self-regulation and are more dependent on external sources of information that flow to them. Therefore, they usually choose the first, closest stimulus. This is largely due to the fact that, under the influence of a strong emotional pressure, they are unable to act effectively, or to think rationally. Research shows that this is also visible when receiving gratification. Children with ADHD are more likely to choose an immediate lower gain than a larger one that must be waited for, because they have poor impulse control [12]. It may also be associated with difficulty in predicting one's own emotional reactions [13]. The child does not have access to a potential repertoire of behaviors, as if strong emotions block cognitive abilities. Therefore, it can be difficult for them to focus or remember lesson material.

Any stimuli coming from the environment evoke certain associations and feelings in a person. Children, who have difficulty in inhibiting reactions, show a reduced ability of delaying emotional reactions, analysis, and reflection [14]. They do not filter information properly. Barkley [15] wrote that this may increase the burden on them and make them more susceptible to emotions such as frustration, fear, disappointment, or sadness. It is much more difficult for them to evoke a positive affect that would help them motivate themselves to finish the activity they have started [10]. Consequently, a tension, that needs to be released, builds up in the child. Therefore, they either react with excessive emotionality or start new activities (usually without ending any of them) [16]. These tasks are most often abandoned or interrupted and involve working on emotions and well-being [10]. This is confirmed by the results of studies in which children with ADHD (with the impulsive and mixed subtype) in the impulsive-reflexive style questionnaire usually exhibit a high state of agitation and impulsiveness (they have shorter reaction times and give less correct answers than children from the control group [10,17-19]. This is often due to the difficulty in selfregulating one's emotions to give the correct answers under the pressure of measured time. According to Barkley [20], this may be due to a decreased ability to objectively assess one's behavior or to estimate one's difficulties by children with ADHD, that is, difficulties with emotional and motivational self-regulation. It can be understood as a style of regulating behavior by delaying one's affective reaction to complete one's behavior properly. At first, it is visible in behavioral attitudes. With time, they become more and more internalized and can manifest themselves in a more cognitive aspect [11].

This understanding is similar as the recent discoveries in the field of neural networks that explain the cognitive self-regulating mechanisms in children with ADHD. Grossberg [21] \& Seidman's iSTAR (Imbalanced Spectrally Timed Adaptive Resonance Theory) describe how the brain controls its behavior (this model is based on two important theories). The first is the Adaptive Resonance Theory (ART), which asserts that the learning process arises as a result of combining an existing memory trace with a new stimulus received through the senses. New memory traces arise only as a result of the mind insufficiently recognizing an object; cognitive conflict is regulated by attentional vigilance. The second theory is the Cognitive-Emotional-Motor Theory of learning. According to it, the new stimulus gains an emotional charge. If individuals have low self-regulation, they will react violently). These researchers, while analyzing neural 
networks in mental disorders, have shown that cognitive ability to recognize events and objects is very important in learning and self-regulation. Cognitive associations give the identified objects an emotional value. Emotions are expressed, depending on the intensity of the cognitive association of the stimulus. Strong excitability of the system causes disturbances in the expression of emotions (inhibition or violent outbursts) [22]. Without selfregulating abilities, a child will not be able to properly respond to an event that is taking place. Children, under the influence of a strong emotional charge, often act impulsively, violently, without reflection - this is when they accept the first solution that comes to their mind and do not analyze it in detail.

Self-regulation can be understood as: a situationsensitive and adaptable approach to planning, initiating, and maintaining an appropriate context (or withdrawing from the context) [23]. This understanding is close to the definition of Barkley [10], who also emphasizes that self-regulation is a reaction or a chain of reactions (thus, a style) by which an individual responds to an event. Furthermore, in the extension of his model, Barkley [10] adds that: self-regulation of motivation allows the child to induce drive states that may be required to initiate and maintain future-oriented behaviors, thus allowing for greater persistence in relation to tasks and activities that may offer little immediate gain as well as from which there may be a significant, delayed gain. Therefore, it can be expected that a child, who does not have proper selfregulation, will respond quickly, impulsively, without much thought, with low correctness.

\section{Metacognitive strategies at school}

Despite the fact that the clinical picture of children with ADHD has been very well known to teachers for years, they incessantly feel helpless when, while assessing knowledge, the student unreasonably marks the first possible answer and completes the test incomparably quickly before the rest of the class. The quickness is disproportionate to the end result. Negative grades multiply in the report card, the motivation of the ADHD student decreases, and psychomotor tension often increases. Recent research reports on metacognitive training for children with ADHD are a ray of hope for both the students with this diagnosis and all passionate teachers $[14,24,25]$.

Metacognition is a concept introduced by the American developmental psychologist Flavell [26]. It determines the ability to recognize one's own cognitive functions and monitor and self-regulate during the ongoing learning process [27]. The development of these skills is crucial to the process of education. Recent studies have shown that students using metacognitive strategies while learning, attain academic success, have a better understanding of science subjects, and broaden vocabulary as well as improve the quality of writing [27, 28]. Such forms of training are successfully used and recommended for children with special educational needs $[14,24,27]$. Among various strategies, Mind Maps and Sketch-noting deserve attention.

The first metacognitive strategy used in this experimental study is the Mind Map, and the second is modified Sketch-noting.

\section{Mind Maps as a metacognitive strategy}

Mind Maps is a technique that was developed by Buzan brothers [29]. Traditional, linear notes are replaced with keywords, diagrams, and drawings to help understand a complex issue better [30]. It can be used both during in-class learning (children draw them in a notebook) and during remote learning. During remote classes the children share the whiteboard with the teacher online and draw a map of the presented issues. Regardless of the mode of schoolwork, each drawn Mind Map has an ordered structure (Fig.1). In the center of the card there is its topic, from which branches extend like rays of the sun, on which there are keywords related to a given category [31].

Mind Maps have several very important advantages. Firstly, students see the entirety of the discussed issue on one sheet, which increases their control over the issues that are discussed in class. This allows them to monitor work better and to focus on the discussed issues. Secondly, students see connections between content, which favors better associating and remembering issues [24,32]. Thirdly, each entry written on the Mind Map should be accompanied by a corresponding picture so that the student can encode the information through words and pictures. In this way, the student activates both analytical and visual thinking [33]. This also contributes to the fact that visual notes are colorful and encourage their creation by students with a reduced motivation to write full sentences (including children with ADHD). In this situation, the phenomenon of counterconditioning occurs. The student begins to associate something he/she once feared and disliked with a nice aspect. However, these are not the only benefits. Empirical research shows that Mind Map training strengthens working memory and reaction inhibition processes in children with ADHD [14,24], and also strengthens self-regulation and motivation to learn in primary school students [33,34]. It would seem to be interesting to see if training with Mind Maps was as effective and enhanced the emotional-motivational selfregulation of students with ADHD.

(Fig. 1) 
Fig.1. Sample Mind Map: Discoverer (student, 11 years).

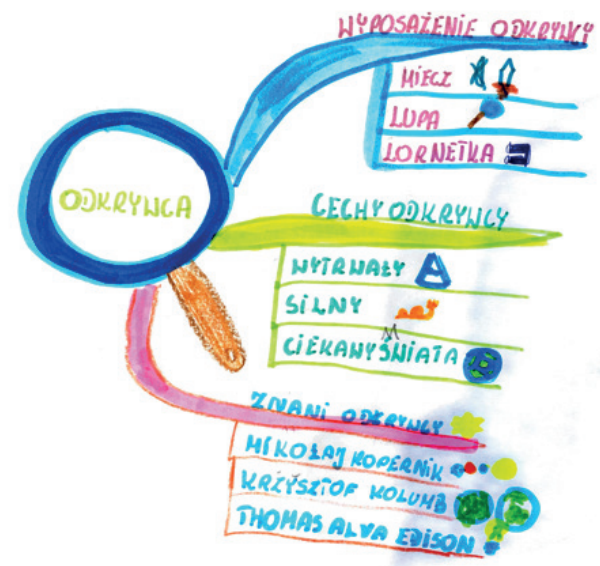

KEY

Odkrywca - Discoverer

Wyposażenie odkrywcy - Discoverer's equipment

Miecz - Sword

Lupa - Magnifying glass

Lornetka - Binoculars

Cechy odkrywcy - Discoverer's character traits

Cierpliwy - Patient

Silny - Strong

Ciekawy świata - Curious about the world

Znani Odkrywcy - Famous discoverers

Mikołaj Kopernik - Nicolaus Copernicus

Krzysztof Kolumb - Christopher Columbus

Tomasz Alva Edison - Thomas Alva Edison

Sketch-noting as a metacognitive strategy

Sketch-noting is the second recommended tool. It is a note-taking technique that relies on sketches, drawings, arrows, dots, commas, boxes, and words (Fig. 2) [35,36]. Children imagine specific content, words, which they then transform in their imagination into a picture [14]. Sketchnoting, unfortunately, does not have the same precise structure as Mind Maps, but proponents of this method also see several benefits from using it on a regular basis. Firstly, it is emphasized that Sketch-noting facilitates conceptual thinking and influences idea generation aimed at solving a given problem [35]. For children with ADHD, this appears to be a key competence that promotes selfregulation. In addition to the ability to create alternative ideas, an important resource in Sketch-noting is the ability to attribute different meanings to a single drawing. Suwa [37] emphasizes that this may also contribute to a new interpretation of the presented phenomenon, which is conducive to creative thinking. Tversky \& Suwa [38] indicate that Sketch-noting is also helpful in organizing ideas and is a medium for expressing the thoughts of the author of the note. Some Sketch-noting practitioners emphasize that when formulating their messages to recipients, it is worth showing them in a drawn form, because it will be easier for them to focus on the content. Text and images can be overwhelming [36]. Summarizing the benefits of using this kind of note in science, it is worth emphasizing that drawing, planning, and expressing one's thoughts through a visual note engages the creator and makes him/her more committed to the learning process.

(Fig. 2)
Fig.2. Sample Sketch-noting entitled Discoverer (student, 11 years)

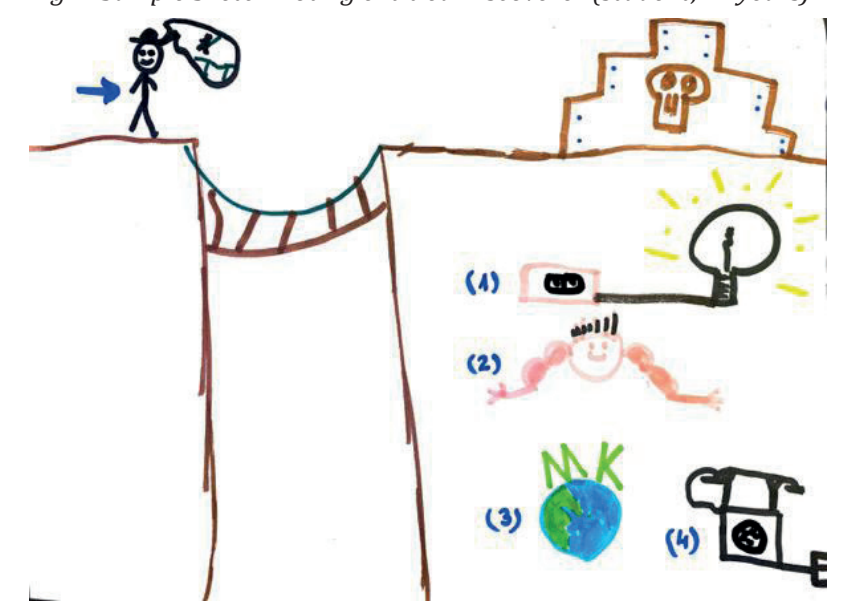

The aim of the presented study is to verify whether the visual methods (Mind Maps and Sketch-noting) considered as metacognitive strategies will help to strengthen emotional and motivational self-regulation in children with ADHD. It was hypothesized that the use of metacognitive strategies, especially Mind Maps, would improve emotional and motivational self-regulation in students with ADHD in relation to children who did not use such methods.

\section{Material and methods}

\section{Study group}

The study was experimental and, in compliance with the highest clinical standards, it was ensured that participants were selected for individual groups randomly. Total number of 135 participants took part in the project, including 45 primary school students diagnosed with attention deficit hyperactivity disorder with the presentation of mixed symptoms $(\mathrm{M}=10.41$; $\mathrm{SD}=1.42)$, their parents $(\mathrm{N}=45)$ and teachers $(\mathrm{N}=$ 45). The diagnosis of ADHD was confirmed by relevant medical and psychological documentation. The students participating in the study did not have comorbidities (the exception being allergies). The participants were taking medications; this was a controlled variable during the study. Based on the medical leaflet, they were divided into preparations that have a positive, negative or neutral effect on children's cognitive performance

\section{Procedure}

The experimental procedure can be divided into four main stages. The first was to recruit people for the study. This was done by purposeful randomization. Children meeting the following conditions were searched for: diagnosis of ADHD with the presentation of mixed symptoms, intellectually normal, without additional somatic diseases and mental disorders. For this purpose, an information leaflet and a poster were prepared and distributed by members of the research team to all 
primary schools and psychological and pedagogical counseling centers in Lublin. Additionally, a Fanpage (ADHD Empirical Research Team) was established, where information about recruitment for the research project was made available. Enrolled children were assigned a code and, based on the number generator, they were randomly assigned to three groups: 1) with the Mind Map strategy, 2) with the Sketch-noting strategy, 3) control (people were informed that they were waiting in the queue for training). Metacognitive training was carried out individually for each student at the university by prepared members of the research team. The trainers were rotationally selected to conduct trainings for children so as to exclude the possibility of a disturbing variable in the form of establishing a relationship between the child and the trainer.

The second phase of the procedure involved inviting the child and parent, presenting the program, and examining the participants. The child got to know the people conducting the research and trainings. At the end of such a meeting, they decided whether they would like to take part in this project, which lasted 3 months. Meetings were held twice a week for 60 minutes. When the participants confirmed their willingness to participate, a psychological examination was carried out on them, and their parents were interviewed and asked to complete their child's health questionnaire with questionnaires. On this occasion, the ADHD symptom severity questionnaire was also submitted to the child's classroom teacher, who was asked to complete and return it the following week.

The final phase was training. The children attended 25 thematic meetings, which were conducted according to handouts, the same way for the Mind Mapping group and Sketch-noting group. The only difference was that in the first group the children answered the trainer's questions and drew elements of the Mind Map on a piece of paper, while in the second group the children, after answering, created drawings corresponding to their associations $[24,14]$. After the last meeting, the children were tested again with psychological tests.

Children, who were in the control group, were pupils diagnosed with ADHD who were tested at the first measurement and then 3 months (equivalent to 25 meetings) later.

\section{Research tools}

Parents, who consented to the participation of their child in the research study, completed a health questionnaire and the Conners 3 ADHD Diagnosis Questionnaire Kit. The full version of this questionnaire was used in the study. The questionnaire contains 108 items to which the completer has to respond on a scale from 0 (not true) to 3 (definitely true). The same tool in the version for the teacher was completed by the child's classroom teachers. With the Conners 3 , it is possible to assess, among other things, the severity of inattention and hyperactivity/impulsivity symptoms as well as the efficiency of executive functions and their impact on children's school skills (only in the teacher's version), Conners Questionnaire 3 is a tool based on DSM 5 criteria, it is very often used both in clinical practice and scientific research, and has satisfactory psychometric properties $[39,40]$.

The children completed the Known Shape Comparison Test (MFF). In this study, it is used to measure emotional-motivational self-regulation understood as a cognitive (reflective/impulsive) style that allows the student to perform academic activities [41]. The MFF is intended for the study of children 9 - 17 years of age. The studied person looks at the pictorial material (12 drawings and 2 samples). After each presented drawing, the child observes 6 versions of a very similar picture. The child's task is to choose the picture that was like the previous one. The time of the child's first reaction is measured and the number of the selected picture is recorded. In this project, the indicators taken into account were: the number of incorrect answers and the child's reaction time [19,42].

\section{Results}

The analysis of variance performed in the first step shows that the groups are homogeneous. There were no statistically significant differences in the first measurement between groups for the variable; emotional and motivational self-regulation (both number of errors and the average reaction time) and learning problems (Tables 1 - 3).

(Table 1)

To test for statistically significant differences between the groups, a one-way analysis of variance (ANOVA) with Bonferroni's post hoc test was also performed on the second measure for the emotionalmotivational self-regulation variable (number of errors). The obtained results indicate that in the second measurement the groups differ significantly from each other $(F(2.42)=4.200 ; p=0.002)$ (Table 1). There is a significant difference between the control group and the Mind Map group. The Wilcoxon signed-rank test was then performed to see if there were statistically significant differences between the first and second measurements for each group. Mean results for the emotional and motivational self-regulation variable (number of errors) indicate statistically significant differences between the first and the second measurement in the group with Mind Maps $\left(\mathrm{M}_{1}=13.33 ; \mathrm{SD}_{1}=4.32 ; \mathrm{M}_{2}=8.90 ; \mathrm{SD}_{2}=3.61\right)$ and in the Sketch-noting group $\left(\mathrm{M}_{1}=15.33 ; \mathrm{SD}_{1}=4.45 ; \mathrm{M}_{2}=12.0\right.$; $\mathrm{SD}_{2}=5.40$ ). However, there are no statistically significant 
Table 1. Comparison of mean results of the emotional and motivational self-regulation variable (number of errors) in the first and second measurement

\begin{tabular}{|c|c|c|c|c|c|c|}
\hline \multirow[b]{2}{*}{ Measurements } & \multicolumn{2}{|c|}{ Control Group } & \multicolumn{2}{|c|}{ Sketch-noting Group } & \multicolumn{2}{|c|}{ Mind Map Group } \\
\hline & I & II & I & II & I & II \\
\hline $\mathrm{Z}$ & \multicolumn{2}{|c|}{1.669} & \multicolumn{2}{|c|}{2.954} & \multicolumn{2}{|c|}{2.84} \\
\hline $\mathrm{p}$ & \multicolumn{2}{|c|}{$\mathrm{n} / \mathrm{s}$} & \multicolumn{2}{|c|}{0.003} & \multicolumn{2}{|c|}{0.005} \\
\hline M & 13.33 & 8.93 & 15.33 & 12 & 14.13 & 13.46 \\
\hline SD & 4.32 & 3.61 & 4.45 & 5.39 & 3.58 & 3.88 \\
\hline $\mathrm{Me}$ & 12 & 8 & 16 & 10 & 14 & 14 \\
\hline Min & 6 & 2 & 18 & 4 & 8 & 6 \\
\hline Max & 20 & 14 & 24 & 20 & 20 & 20 \\
\hline & \multirow{4}{*}{\multicolumn{2}{|c|}{ ANOVA }} & \multicolumn{2}{|c|}{ Measurement I } & \multicolumn{2}{|c|}{ Measurement II } \\
\hline & & & \multicolumn{2}{|c|}{$F(2.42)=0.889$} & \multicolumn{2}{|c|}{$F(2.42)=4.200$} \\
\hline & & & \multicolumn{2}{|c|}{$\mathrm{p}=\mathrm{n} / \mathrm{s}$} & \multicolumn{2}{|c|}{$\mathrm{p}=0.02$} \\
\hline & & & \multicolumn{4}{|c|}{$\mathrm{MM}>\mathrm{K}^{* *}$} \\
\hline
\end{tabular}

Annotation: ${ }^{*} p=0.05 ;{ }^{* *} p=0.001$

differences between the first and second measurements in the control group. A rank-biserial correlation coefficient indicating the effect size index was also calculated for the group with Mind Maps and Drawings (respectively: $r_{c}$ $=0.73 ; r_{c}=0.76$ ). The value of the rank-biserial correlation coefficient indicates that the effect is large. This means that children who have participated in the training with Mind Maps and Drawings make significantly fewer errors in the second measurement, and the quantitative power of this phenomenon can be considered high.

(Table 2)

In order to check whether there are statistically significant differences between the groups, in the second measurement for the emotional-motivational self-regulation variable (mean reaction time), a one-way analysis of variance (ANOVA) was also performed. The

Table 2. Comparison of mean results of the emotional and motivational self-regulation variable (average reaction time) in the first and second measurement

\begin{tabular}{|c|c|c|c|c|c|c|}
\hline \multirow[b]{2}{*}{ Measurements } & \multicolumn{2}{|c|}{ Control Group } & \multicolumn{2}{|c|}{ Sketch-noting Group } & \multicolumn{2}{|c|}{ Mind Map Group } \\
\hline & I & II & I & II & I & II \\
\hline $\mathrm{Z}$ & \multicolumn{2}{|c|}{1.433} & \multicolumn{2}{|c|}{2.040} & \multicolumn{2}{|c|}{0.028} \\
\hline $\mathrm{p}$ & \multicolumn{2}{|c|}{$\mathrm{n} / \mathrm{s}$} & \multicolumn{2}{|c|}{0.04} & \multicolumn{2}{|c|}{$\mathrm{n} / \mathrm{s}$} \\
\hline M & 10.69 & 11.88 & 9.50 & 10.53 & 8.94 & 8.78 \\
\hline SD & 8.25 & 10.44 & 5.95 & 6.75 & 4.75 & 4.95 \\
\hline $\mathrm{Me}$ & 9.48 & 7.72 & 8.16 & 8.02 & 7.31 & 6.95 \\
\hline Min & 2.26 & 4.18 & 2.46 & 2.92 & 2.24 & 2.56 \\
\hline Max & 36.58 & 37.56 & 23.16 & 23.16 & 18.27 & 16.99 \\
\hline & \multirow{3}{*}{\multicolumn{2}{|c|}{ ANOVA }} & \multicolumn{2}{|c|}{ Measurement I } & \multicolumn{2}{|c|}{ Measurement II } \\
\hline & & & \multicolumn{2}{|c|}{$F(2.42)=0.282$} & \multicolumn{2}{|c|}{$F(2.42)=0.604$} \\
\hline & & & \multicolumn{2}{|c|}{$\mathrm{p}=\mathrm{n} / \mathrm{s}$} & \multicolumn{2}{|c|}{$\mathrm{p}=\mathrm{n} / \mathrm{s}$} \\
\hline
\end{tabular}

obtained results indicate that there are no statistically significant differences in the second measurement between the groups (Table 2). Analysis with the Wilcoxon signed-rank test showed that in the Sketchnoting group, the mean results for the emotional and motivational self-regulation variable (reaction time) are statistically significant differences in the severity of the means between the first measurement and the second measurement $\left(\mathrm{M}_{1}=9.50 ; \mathrm{SD}_{1}=5.95 ; \mathrm{M}_{2}=10.53 ; \mathrm{SD}_{2}=6.75\right)$. Such differences were not noted in the other groups. For the Sketch-noting group, the rank-biserial correlation coefficient was also calculated, specifying the effect size index $\left(r_{c}=0.53\right)$. Its value indicates that the effect is large. This means that children, who participated in training with Sketch-noting, increased their first reaction time, and the quantitative power of this phenomenon can be 
Table 3. Comparison of the results of the means of the learning problems variable in the first and second measurement assessed by parents and teachers

\begin{tabular}{|c|c|c|c|c|c|c|}
\hline \multicolumn{7}{|c|}{ Parents } \\
\hline & \multicolumn{2}{|c|}{ Control Group } & \multicolumn{2}{|c|}{ Sketch-noting Group } & \multicolumn{2}{|c|}{ Mind Map Group } \\
\hline Measurements & I & II & I & II & I & II \\
\hline $\mathrm{Z}$ & \multicolumn{2}{|c|}{1.63} & \multicolumn{2}{|c|}{0.358} & \multicolumn{2}{|c|}{1.014} \\
\hline $\mathrm{p}$ & \multicolumn{2}{|c|}{$\mathrm{n} / \mathrm{s}$} & \multicolumn{2}{|c|}{$\mathrm{n} / \mathrm{s}$} & \multicolumn{2}{|c|}{$\mathrm{n} / \mathrm{s}$} \\
\hline M & 11.66 & 12.26 & 14.2 & 13.26 & 11.6 & 10.73 \\
\hline SD & 5.57 & 5.58 & 5.63 & 9.23 & 5.69 & 5.77 \\
\hline $\mathrm{Me}$ & 13 & 13 & 17 & 10 & 11 & 11 \\
\hline Min & 3 & 4 & 4 & 2 & 4 & 2 \\
\hline Max & 19 & 19 & 21 & 33 & 24 & 25 \\
\hline & \multirow{3}{*}{\multicolumn{2}{|c|}{ ANOVA }} & \multicolumn{2}{|c|}{ Measurement I } & \multicolumn{2}{|c|}{ Measurement II } \\
\hline & & & \multicolumn{2}{|c|}{$F(2.42)=1.038$} & \multicolumn{2}{|c|}{$F(2.42)=1.117$} \\
\hline & & & \multicolumn{2}{|c|}{$\mathrm{p}=\mathrm{n} / \mathrm{s}$} & \multicolumn{2}{|c|}{$\mathrm{p}=\mathrm{n} / \mathrm{s}$} \\
\hline \multicolumn{7}{|c|}{ Teachers } \\
\hline & \multicolumn{2}{|c|}{ Control Group } & \multicolumn{2}{|c|}{ Sketch-noting Group } & \multicolumn{2}{|c|}{ Mind Map Group } \\
\hline Measurements & $\mathrm{I}$ & II & I & II & I & II \\
\hline $\mathrm{Z}$ & \multicolumn{2}{|c|}{1.134} & \multicolumn{2}{|c|}{1.73} & \multicolumn{2}{|c|}{2.041} \\
\hline $\mathrm{p}$ & \multicolumn{2}{|c|}{$\mathrm{n} / \mathrm{s}$} & \multicolumn{2}{|c|}{$\mathrm{n} / \mathrm{s}$} & \multicolumn{2}{|c|}{0.04} \\
\hline M & 7.86 & 7.66 & 9 & 8.33 & 6.06 & 5.66 \\
\hline SD & 4.94 & 4.82 & 4.44 & 4.48 & 4.19 & 3.53 \\
\hline $\mathrm{Me}$ & 8 & 8 & 8 & 8 & 5 & 6 \\
\hline Min & 1 & 1 & 4 & 2 & 1 & 1 \\
\hline Max & 15 & 15 & 17 & 18 & 18 & 15 \\
\hline & \multirow{3}{*}{\multicolumn{2}{|c|}{ ANOVA }} & \multicolumn{2}{|c|}{ Measurement I } & \multicolumn{2}{|c|}{ Measurement II } \\
\hline & & & \multicolumn{2}{|c|}{$F(2.42)=1.594$} & \multicolumn{2}{|c|}{$F(2.42)=1.552$} \\
\hline & & & \multicolumn{2}{|c|}{$\mathrm{p}=\mathrm{n} / \mathrm{s}$} & & \\
\hline
\end{tabular}

considered extensive.

(Table 3)

In the last step, it was checked whether there were statistically significant differences between the groups in the second measurement for the learning problems variable assessed by both parents and teachers. The results of the one-way analysis of variance indicate that there are no significant differences between the groups in the assessment of learning problems in children with ADHD, in the assessment of both parents and teachers (Table 3). Analysis with the Wilcoxon signed-rank test also showed no significant differences between the first and second measurement in all groups (when assessed by parents), except for the teacher-assessed Mind Map group. The analysis showed that in this group, the mean scores for the severity of learning problems in children with ADHD are statistically significant, lower in the second measurement compared to the first $\left(M_{1}=6.06\right.$; $\mathrm{SD}_{1}=4.19 ; \mathrm{M}_{2}=5.66 ; \mathrm{SD}_{2}=3.53$ ). For the Mind Map group, the rank-biserial correlation coefficient was also calculated, specifying the effect size index ( $\mathrm{rc}=0.31)$. Its value indicates that the effect is moderate. This means that children who participated in the Mind Map training had significantly fewer learning problems when their teachers assessed them in the second measurement compared to the first, and the quantitative strength of this phenomenon can be considered average.

\section{Discussion}

The subject of this experimental study was to assess the impact of training with two metacognitive strategies on the emotional and motivational self-regulation of children with ADHD and the severity of learning problems that were assessed by parents and teachers. So far, the 
literature has indicated an improvement in emotional and motivational self-regulation in children [33]. There was no assessment of the impact of metacognitive training on the self-regulation of children from clinical groups, in this case children diagnosed with ADHD. So far, working memory, response inhibition processes and executive functions have been assessed in general $[14,24,25]$. The construct of emotional and motivational self-regulation is also significant for goal-oriented behavior, including learning processes. The results obtained in the study indicate that after 25 training sessions with the use of both Mind Maps and Sketch-noting, children with ADHD make significantly fewer errors than during the first measurement. However, only in the Sketch-noting group did their average reaction time increase significantly, which indicates that they are more reflective. It should be pointed out that the obtained results are consistent with the theoretical studies. Joshi [34], in describing the benefits of using Mind Maps, points to the improvement of self-regulation. According to the researcher, writing an idea on a piece of paper helps to generate numerous ideas and organise both those on the sheet of paper and those in the head. This researcher emphasises the particular role of controlling the problem. In the case of the prolonged average time of the first reaction in the Sketch-noting group, it should be noted that the tests measuring the self-regulation ability in this study were based on visual material; therefore, children in drawing-only training could be particularly sensitive to visual stimuli. Nevertheless, this seems to be worthy of wider exploration in future research, as enhancing emotional and motivational self-regulation increases reflectivity and criticism. These skills are particularly important in the processes of effective learning. In this study we also wanted to check whether the participation of children in regular training would translate into them having fewer learning difficulties, which were assessed by both parents and teachers of these children. These studies show that teachers perceive significantly fewer learning problems in children with ADHD, but only in the group with Mind Maps. These observations could be supported by the study of Mulligan [43]. It was noted in the study that teachers

\section{Limitations of own research}

A limitation of long-term experimental studies is usually the small sample size. This is also the limitation in this study. Therefore, despite the fact that the corresponding non-parametric tests were used, the obtained results should be approached with caution. In the future, it is worth conducting a similar study on a larger group of people.

\section{Conclusions}

Despite the fact that children attended training before the COVID pandemic, the conclusions of this study may provide a basis for further exploration. The presented metacognitive strategies can be successfully applied at school by students with ADHD and constitute a source of support for both students and teachers. Metacognitive strategies need much more attention from researchers, as they can potentially not only be relevant to the learning of children with special educational needs, but also constitute a therapeutic form of support for children with ADHD.

\section{Acknowledgements}

The authors of this work would like to express their sincere thanks to the members of the ADHD Empirical Research Team and all participants of this project.

\section{Manuscript funding}

The publication of the manuscript was co-financed by a grantfrom the Institute of Psychology of the John Paul II Catholic University of Lublin, headed by Agnieszka Kulik.

\section{Conflict of interest}

The authors have declared no conflict of interest.

\section{References:}

1. Barnard-Brak L, Stevens T, Albright E. Academic redshirting and academic achievement among students with ADHD. Contemp Educ Psychol. 2017;50:4-12. doi:10.1016/j. cedpsych.2015.10.001

2. Lindsay G, Wedell K, Dockrell J. Warnock 40 Years on: The Development of Special Educational Needs Since the Warnock Report and Implications for the Future. Front Educ. 2020;4:164. doi:10.3389/feduc.2019.00164

3. Ministerstwo Edukacji Narodowej. Specjalne potrzeby edukacyjne dzieci i młodzieży. Prawne ABC dyrektora przedszkola, szkoły i placówki. Warszawa; Ministerstwo Edukacji Narodowej: 2010. https://static.scholaris.pl/ mainfile/102/539/specjalne_potrzeby_edukacyjne_66014.pdf. Dostęp 28.12.2021.

4. DuPaul GJ, Langberg JM. Educational Impairments in Children with ADHD. In Barkley RA, ed., Attention-Deficit Hyperactivity Disorder: A Handbook for Diagnosis and Treatment. New York; The Guilford Press: 2015:169-190.

5. Newton KJ, Sperling RA, Martin AJ. Learning disabilities, attention-deficit hyperactivity disorder, and executive functioning: Contributions from educational psychology in progressing theory, measurement, and practice [Editorial]. Contemp Educ Psychol. 2017;50:1-3. doi:10.1016/j. cedpsych.2016.12.003

6. Pinto C, Baines E, Bakopoulou I. The peer relations of pupils with special educational needs in mainstream primary schools: The importance of meaningful contact and interaction with peers. Br J Educ Psychol. 2019;89(4):818-837. doi:10.1111/ bjep.12262

7. Roberts W, Milich R, Barkley RA. Primary symptoms, diagnostic 
criteria, subtyping, and prevalence of ADHD. In Barkley RA, eds., Attention-Deficit Hyperactivity Disorder: A Handbook for Diagnosis and Treatment. New York; The Guilford Press: 2015:51-80

8. Becker SP, Breaux R, Cusick CN, Dvorsky MR, Marsh NP, Sciberras E,et all. Remote Learning During COVID-19: Examining School Practices, Service Continuation, and Difficulties for Adolescents With and Without Attention-Deficit/Hyperactivity Disorder. J Adolesc Health. 2020;67(6):769-777. doi:10.1016/j. jadohealth.2020.09.002

9. Shah R, Raju VV, Sharma A, Grover S. Impact of COVID-19 and Lockdown on Children with ADHD and Their Families-An Online Survey and a Continuity Care Model. J Neurosci Rural Pract. 2021;12(1):71-79. doi:10.1055/s-0040-1718645

10. Barkley RA. Behavioral inhibition, sustained attention, and executive functions: Constructing a unifying theory of ADHD. Psychol Bull. 1997;121(1):65-94. doi:10.1037/00332909.121.1.65

11. Barkley RA. The executive functions and self-regulation: an evolutionary neuropsychological perspective. Neuropsychol Rev. 2001;11(1):1-29. doi:10.1023/a:1009085417776

12. Marx I, Hacker T, Yu X, Cortese S, Sonuga-Barke E. ADHD and the Choice of Small Immediate Over Larger Delayed Rewards: A Comparative Meta-Analysis of Performance on Simple Choice-Delay and Temporal Discounting Paradigms. J Atten Disord. 2021;25(2):171-187. doi:10.1177/1087054718772138

13. Kajka N, Kulik A. The Influence of Metacognitive Strategies on the Improvement of Reaction Inhibition Processes in Children with ADHD. Int J Environ Res Public Health. 2021;18(3):878. doi:10.3390/ijerph18030878

14. Kajka N, Kulik A. Assessment of emotional control from the perspective of young adults with ADHD. Społeczeństwo. Edukacja. Język $14.2 \quad$ (2021):41-54. doi:10.19251/ sej/2021.14.2(4)

15. Barkley RA. Response Inhibition in Attention-Deficit Hyperactivity Disorder. Ment Retard Dev Disabil Res Rev. 1999;5:177-184. doi:10.1002/(SICI)10982779(1999)5:3<177::AID-MRDD3>3.0.CO;2-G

16. Kajka N. Uwarunkowania rozwoju społeczno- emocjonalnego dziecka z ADHD w środowisku szkolnym. Problemy Opiekuńczo - Wychowawcze. 2017;2:11-17.

17. Drechsler R, Rizzo P, Steinhausen H-C. The impact of instruction and response cost on the modulation of responsestyle in children with ADHD. Behav Brain Funct. 2010;6:31. doi:10.1186/1744-9081-6-31

18. DuPaul GJ, Anastopoulos A D, Shelton T L, Guevremont D C, Metevia L. Multimethod Assessment of Attention-Deficit Hyperactivity Disorder: The Diagnostic Utility of Clinic-Based Tests. J Clin Child Adolesc Psychol. 1992;21(4): 394-402. doi:10.1207/s15374424jccp2104_10

19. Kagan J. Reflection-impulsivity: the generality and dynamics of conceptual tempo. J Abnorm Psychol. 1966;71(1):17-24 doi:10.1037/h0022886

20. Barkley RA. Impaired delayed responding: A unified theory of attention-deficit hyperactivity disorder. In Routh DK, ed. Disruptive Behavior Disorders in Childhood. Boston; Springer, MA: 1994:11-57. doi:10.1007/978-1-4899-1501-6_2

21. Grossberg S, Seidman D. Neural dynamics of autistic behaviors: Cognitive, emotional, and timing substrates. Psychol Rev. 2006;113(3):483-525. doi:10.1037/0033-295x.113.3.483

22. Duch W, Dobosz K. Sieci neuronowe w modelowaniu chorób psychicznych. W: Tadeusiewicz R, Duch W, Korbicz J, Rutkowski L, eds., Sieci neuronowe w inżynierii biomedycznej. Warszawa; Wydawnictwo Exit: 2013:637-666.
23. Lohman DF, Bosma A. Using cognitive measurement models in the assessment of cognitive styles. In Braun HI, Jackson DN, Wiley DE, eds., The Role of Constructs in Psychological and Educational Measurement. New York; Lawrence Erlbaum Associates Publishers: 2001:127-146.

24. Kajka N. The influence of metacognitive training on the improvement of working memory in children with ADHD. Curr Probl Psychiatry. 2019;20(3):217-227. doi:10.2478/cpp-20190015

25. Tamm L, Nakonezny PA. Metacognitive executive function training for young children with ADHD: a proof-of-concept study. Atten Defic Hyperact Disord. 2015;7(3):183-190. doi:10.1007/s12402-014-0162-x

26. Flavell JH. Metacognition and cognitive monitoring: A new area of cognitive-developmental inquiry. Am Psychol. 1979;34(10):906-911. doi:10.1037/0003-066X.34.10.906

27. Pezzica S, Vezzani C, Pinto G. Metacognitive knowledge of attention in children with and without ADHD symptoms. Res Dev Disabil. 2018;83:142-152. doi:10.1016/j.ridd.2018.08.005

28. Pisacco N, Sperafico Y, Enricone J, Guimarães L, Rohde LA, Dorneles BV. Metacognitive interventions in text production and working memory in students with ADHD. Psicol Refl Crít. 2018;31(1):5. doi:10.1186/s41155-017-0081-9

29. Buzan T, Buzan B. The Mind Map Book. London; BBC Books: 1993.

30. Almulla MA, Alamri MM. Using Conceptual Mapping for Learning to Affect Students' Motivation and Academic Achievement. Sustainability. 2021;13(7):4029. doi:10.3390/ su13074029

31. Kalyanasundaram M, Abraham SB, Ramachandran D, Jayaseelan V, Bazroy J, Singh Z, et all. Effectiveness of Mind Mapping Technique in Information Retrieval Among Medical College Students in Puducherry-A Pilot Study. Indian J Community Med. 2017;42(1):19-23. doi:10.4103/0970-0218.199793

32. Kajka N. Trudności $\mathrm{w}$ nauce czytania i pisania u dzieci ADHD. Szkoła Specjalna. 2018;3:212-218 . http://www. szkolaspecjalna.aps.edu.pl/media/2129755/sz-s_3-18_druk. pdf. Dostęp 28.12.2021.

33. Tanriseven I. A Tool That Can Be Effective in the Selfregulated Learning of Pre-service Teachers: The Mind Map. Aust J Teach Educ. 2014;39(1). doi:10.14221/ ajte.2014v39n1.1

34. Joshi CV. Use of Simple Mind Maps in the Adventures of Learning. J Contemp Res Manag. 2017;4(1):1-11.

35. Fernández-Fontecha A, O'Halloran KL, Tan S, Wignell P. A multimodal approach to visual thinking: the scientific sketchnote. Vis. Commun. 2019;18(1):529. doi:10.1177/1470357218759808

36. Perry K, Weimar H, Bell MA. Sketchnoting in School: Discover the Benefits (and Fun) of Visual Note Taking. Lanham; Rowman \& Littlefield: 2017.

37. Suwa M. Seeing into sketches: Regrouping parts encourages new interpretations. In: Gero JS. eds., Visual and Spatial Reasoning in Design. Sydney; Key Centre of Design Computing and Cognition: 2001:207-219.

38. Tversky B, Suwa M. Thinking with sketches. In: Markman AB, Wood KL eds., Tools for Innovation. Oxford; Oxford University Press:2009:75-85.

39. Conners CK, Rzepa SR, Pitkanen J, Mears S. Conners 3rd Edition (Conners 3; Conners 2008). In: Kreutzer JS, DeLuca J, Caplan B. eds., Encyclopaedia of Clinical Neuropsychology. Springer, Cham.:2018. https://doi.org/10.1007/978-3-319-57111-9_1534

40. Wujcik R, Wrocławska - Warchala E. Conners 3 (). Zestaw kwestionariuszy do diagnozy ADHD i zaburzeń 
współwystępujących. Wydanie trzecie. Podręcznik. Warszawa; Pracownia Testów Psychologicznych Polskiego Towarzystwa Psychologicznego:2018.

41. Nietfeld J. Bosma A. Examining the self-regulation of impulsive and reflective response styles on academic tasks. J Res Pers. 2003; 32:118-140. doi:10.1016/S0092-6566(02)00564-0

42. Matczak A. Test Porównywania Znanych Kształtów (MFF) J. Kagan. Podręcznik. Warszawa; Pracownia Testów Psychologicznych Polskiego Towarzystwa Psychologicznego:1992.

43. Mulligan S. Classroom strategies used by teachers of students with attention deficit hyperactivity disorder. Phys Occup Ther Pediatr. 2001;20(4):25-44.

44. Narad, Megan E et al. "Parent-teacher agreement on ADHD symptoms across development." Psychological assessment vol. 27,1 (2015): 239-48. doi:10.1037/a0037864

\section{Corresponding author}

Natalia Kajka

I Department of Psychiatry, Psychotherapy and Early Intervention ,Medical University of Lublin

e-mail: nataliakajka@umlub.pl

Otrzymano: 29.12.2021

Zrecenzowano: 14.01.2022

Przyjęto do druku: 04.02.2022 